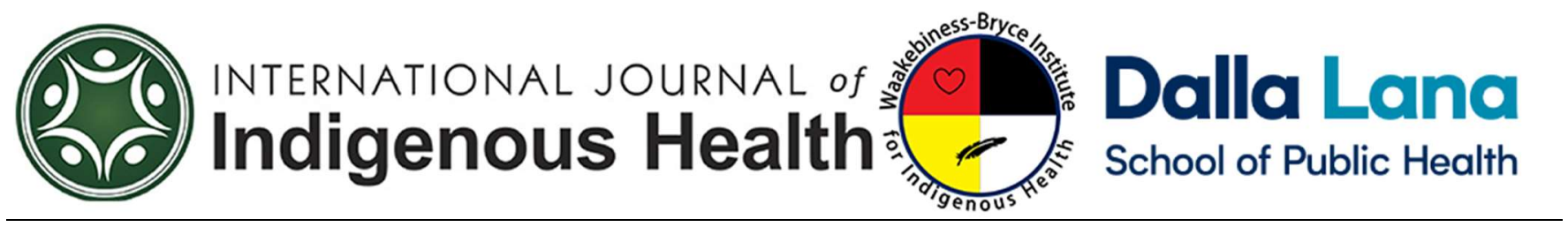

Volume 14

Issue 1. Physical Activity and Cultural Safety

Article 6

DOI 10.32799/ijih.v14i1.31932

May 2019

\title{
Building on Strengths: Collaborative Intergenerational Health Research with Urban First Nations and Métis Women and Girls
}

Elizabeth Cooper, PhD.

Faculty of Health Sciences, University of the Fraser Valley

elizabeth.cooper@ufv.ca

Michelle Driedger, $\mathrm{PhD}$

Community Health Sciences, Rady Faculty of Health Sciences, University of Manitoba

michelle.driedger@umanitoba.ca

Josée Lavoie, $\mathrm{PhD}$

Community Health Sciences, Rady Faculty of Health Sciences, University of Manitoba

josee.lavoie@umanitoba.ca

\section{Acknowledgements}

We would like to thank the women and girls who participated in this study, and acknowledge the families and community members who supported their participation. We would like to thank the Manitoba Metis Federation Health and Wellness Department for their support of this study. We would also like to thank Dr. Heather Castleden and Dr. Tuula Heinonen for reviewing earlier drafts of this paper. We would also like to acknowledge support provided by the Michael Smith Health Research Foundation and the Canadian Federation for Innovation and Manitoba Research and Innovation Fund: 202990.

Follow the International Journal of Indigenous Health at: https://jps.library.utoronto.ca/index.php/ijih/index

\section{Recommended Citation}

Cooper, E., Driedger, M., Lavoie, J. (2019). Building on Strengths: Collaborative Intergenerational Health Research with Urban First Nations and Métis Women and Girls. IJIH,14(1),107- 125.

DOI:10.32799/ijih.v14i1.31932 


\title{
A Building on Strengths: Collaborative Intergenerational Health Research with Urban First Nations and Métis Women and Girls.
}

\begin{abstract}
Little research has focused on how Indigenous girls and their familial female caregivers negotiate issues pertaining to wellbeing and decision-making practices. To address this gap, we employed a novel intergenerational Indigenous partnership methods using various decolonizing action and arts-based activities, to allow participants to guide and modify the direction of the research throughout data collection. We report on three separate activities: a physical game to address concepts of wellness, a memory game that focused on harm reduction and an art project that explored self-esteem. Within each of these activities, female family members and girls worked together to unpack issues of importance within their lives. We conclude that a flexible participatory research design within an intergenerational setting can meet not only the proposed research objectives, but participants' ever-changing questions and concerns pertaining to health and wellbeing, while still producing rich data to answer important research questions.
\end{abstract}

\section{Keywords}

Aboriginal, Canada, Manitoba, Autochthones, First Nations, Participatory-Action Research, Arts-Based Research

\section{Creative Commons Licence}

\section{(ब) $\Theta$}

This work is licensed under a Creative Commons Attribution-Noncommercial-No Derivative Works 4.0 License. 


\section{Introduction}

Ideally, Indigenous health research aims to develop and use strengths-based methods. These methods need to simultaneously provide opportunities to: meet academic objectives, have academic rigour, appeal to participants, and meet participants where they are at, as opposed to where researchers think they ought to be. Strengths-based methods create spaces where participants can explore issues that are of importance to them, feel comfortable engaging with the methods being used, and, where possible, create opportunities for skill building. In 2015-16, we undertook a participatory strength-based study with girls (ages 8-12) and female familial caregivers to explore health and wellness. The main objectives that guided the academic component of the study included: the exploration of individual health decisionmaking practices; and barriers to the uptake of knowledge translation products, especially those with best-practice guidelines. A key finding was that the methods used need to engage participants, and by extension patients, on multiple levels.

\section{Background}

The last five years have seen many important milestones within the Indigenous and nonIndigenous landscape within Canada that promote strengths-based platforms for change. Many of these stem from efforts to acknowledge the legacy of harms caused by colonial and neocolonial practices and policies. Idle No More (2012-2013) called public attention to land sovereignty and Indigenous rights. The Truth and Reconciliation Commission report (TRC, 2015) called public attention to the legacy of the residential schools and shed public light on issues and experiences that have too long been silenced. The Missing and Murdered Indigenous Women and Girls Inquiry (2016) has raised public awareness about racialized violence. In October 2017, the Canadian government announced that a financial settlement will be offered to status First Nations and Inuit children who were part of the sixties scoop (Tasker, 2017). Indigenous peoples in Canada and elsewhere are demanding that treaties be honoured, traditions valued and positive changes take place.

We argue that research processes can either perpetuate or counter past and continued harms embedded in policies, which entrench power imbalance and undermine families' integrity. We believe that ensuring decision-making opportunities for participants are a central tenant for research methods used, and helps ensure that participating in research is not causing more harm than good. Conducting research that seeks to disrupt harmful practices while gathering pertinent data is largely shaped by the methods used. In this article, we present the results of a study that combined multiple methods in order to create an intergenerational workshop aiming to foster meaningful dialogue. The research design was informed by Indigenous research methods including a shifting of power relations and the incorporation of traditional knowledge (Funston, 2013; Rothe, Ozegovic, \& Carroll, 2009; Walker, Fredericks, Mills, $\&$ Anderson, 2014). These are different from decolonizing methods that aim to disrupt the status quo (Adelson, 2009; Duran, Duran, Yellow Horse Brave Heart, \& Yellow Horse-Davis, 1998; Episkenew, 
2009; Linklater, 2014; Prussing, 2014; Schwan \& Lightman, 2015; Tuhiwai-Smith, 2006), although the two can be used together.

Participatory and qualitative methods complement Indigenous and decolonizing methods, especially in research that aims to create a suitable space that is accessible and acceptable for ethical research (Kovach, 2009; Tuhiwai-Smith, 2006). By combining decolonizing, action (Chambers, 2002; Wang \& Burris, 1997), and community based research methods (Blumenthal, 2011; Minkler, 2005), we created a vibrant space for data collection with children and adults about health and wellbeing to take place.

\section{Methods}

Participants were recruited to take part weekly in a seven-week long workshop, referred to as "Girls Night Out" through the distribution of posters and word of mouth at non-profit organizations that work with both women and children within the city. The workshop was conducted on three separate occasions between September 2015 and March 2016 (university ethics approval H2015:169).

Participants were recruited based on self-identification as an Indigenous female primary familial caregiver (mother, grand-mother or female relative, or foster mother) of a girl between the ages of 8-12 years willing to commit to attending a weekly workshop with her child, or children, for the duration of the program. Participants took part in a 2-3 hour weekly activity program that included provision of a meal.

Adults provided written or audio recorded consent for both their participation, and that of the children within their care who participated in the study. Girls provided written or audio recorded assent before data was collected. Participants were reminded throughout the seven weeks that they did not have to participate in any activity that they were not comfortable being a part of, and that their participation did not need to be included in the data collection process. If either adult or child participants did not want an element of their participation included in the data, they were asked to inform the lead researcher or research assistant either verbally or in writing (e.g. by text), at any point during the research process and the month following the completion of data collection. Given the historical erasure of Indigenous identity (e.g. a photo labeled only as plains Indian woman), participants were provided the option of having direct quotes attributed with the name they were known by within the research process or a pseudonym. All participants requested that their first names be used when depicting results. As women collectively referred to all girls as "my girl", or daughter, regardless of the familial relationship with the girls, the term daughter is used in this paper to refer to the adult-child relationship. Each data collection period ended with a community feast. At this feast, adult participants received a $\$ 50$ honorarium and girls received a gift valued at $\$ 20$ to thank them for participation. In addition, participants received a certificate of participation, individualized storybooks and a workshop-specific workbook. 
The research objectives were determined collaboratively with the advisory committee, and workshop objectives were developed with participants on the first week of data collection. The advisory committee was comprised of members from the Manitoba Metis Federation Health and Wellness Department, and professors on Cooper's $\mathrm{PhD}$ dissertation committee. The workshop was divided into twenty-minute segments, though participants often took longer than anticipated to complete an activity. A typical evening would begin with an icebreaker activity or game; followed by a game used to generate a discussion activity; a craft; dinner, which typically took forty minutes; another craft or game; and a closing discussion and planning for the following week (see a detailed session guide for the nutrition night found in Appendix 1). Participants determined key themes for exploration such as self-care, nutrition, and personal safety. Participants also provided insight into the kinds of activities they would like to undertake and questions they would like to address.

Data collected included photographs $(\mathrm{n}=877)$ taken during the workshops and of art projects, videos ( $\mathrm{n}=99$, total video time: 3 hours, $14 \mathrm{~min}$ and 39 seconds), audio recordings $(\mathrm{n}=19$, total audio time: 7 hours and four minutes), and 60 hours of participant observation (field notes were completed). Many participants were uncomfortable speaking on camera or when the audio recorder was turned on, especially about challenges they were facing or questions they had about specific skills or access to services. Participants had the opportunity to identify key themes that emerged each week and were provided with initial thematic descriptive findings prior to the commencement of further academic data analysis or writing of any academic publications.

Data was organized using NVivo $9 \mathrm{M}$. An inductive process was used to analyze the data. A coding guide was developed using data driven themes (e.g. nutrition, self-care, family), as well as informed by different theories to better understand participant experiences (e.g. gender, colonization, harm-reduction). Transcripts and descriptive notes were coded, and re-coded for consistency (Braun \& Clarke, 2006; Guest, MacQueen, \& Namey, 2012; Hankivsky et al., 2014).

\section{Relationship}

The research was overseen by an advisory committee comprised of academics and members from the Manitoba Metis Federation-Health \& Wellness Department. The research and workshop facilitation team was comprised of the lead researcher and research assistant with a background in child development, with a focus on complex traumas. The researchers did not have any relationship with the participants, however some of the participants knew each other prior to participating in the study.

\section{Results}

When participants expressed interest in the study, they were told more about what their participation in the study would involve; namely, that they would be asked to regularly provide input 
about the content included in the weekly workshops to ensure that everything met their ever evolving needs and interests. It was explained that the experience of participating in the research study would be interactive and engaging for both adults and children, where we (researchers and participants) could actively learn together. Participants were also told that the aim of the workshops was to provide opportunities for them to do activities they enjoyed together not only as members of families, but as a community of people participating in the research process. In addition to research objectives, a series of workshop objectives were developed with participants (women and girls aged 8-12) on the first week of each series of workshops. Workshop objectives included: 1) creation of a workshop that highlighted opportunities for intergenerational programming and relationship building; 2) exploring the importance of health and happiness for First Nations and Metis girls and their female familial caregivers; 3) providing skill-building opportunities to understand public health messaging; and 4) providing a supportive space for personal growth and increased interest in wellbeing and health literacy. While the workshop objectives were complimentary to the research objectives, they were not the same. Activities designed specifically to meet workshop objectives did not always lend themselves to data collection. We will focus on how participant identified objectives were embedded into three data collection methods used: a medicine wheel game, a memory game and an art project that engaged popular media. Participants were offered the option of having their name associated with direct quotes or being anonymous. Within this paper, the lack of names associated with direct quotations is a response to the ability to attribute names in group discussions when multiple children and adults are talking simultaneously rather than a reflection of the wish to remain anonymous or not.

\section{Participant Characteristics}

All participants (24 women and 36 girls) identified as First Nations, Metis, or both and lived within the urban centre. All of the girls were registered at public schools, although attendance varied. Most of the adults were employed or were attending school full-time. All of the women reported that they had completed high school and the majority of women reported at least some post-secondary education. Most children had father-figures who were actively involved in their lives, and all participants had close ties to extended relatives. Family income ranged from under $\$ 10,000$ to over $\$ 100,000 \mathrm{CDN}$ with most families earning between $\$ 50,000-74,000 \mathrm{CDN}$.

\section{An Intergenerational Space for Data Collection}

There were two key issues raised by participants that changed the way that the workshops were initially envisioned by the advisory group: the inclusion criteria; and the ability of girls to be central participants in all aspects of data generation and workshop programming decisions. Initially, this research was to be Metis-specific. In the initial phase of advertising the study, potential participants 
noted that their families and communities are comprised of both First Nations and Metis citizens. In addition, they noted that it is essential to work collectively within urban centres to address the needs of Indigenous peoples. As a response, they requested that anyone who self-identified as Indigenous be invited to participate. The other modification participants requested was the equal involvement of girls in all of the activities. The initial design involved participation by girls in some research activities with their caregivers during the first half hour of the evening workshops, eating dinner as a group, and then moving onto completing other non-research related activities in a different part of the space with a trained childcare staff. Women voiced that the girls were old enough to understand why decisions were being made, often stating that they had become parents when they were not much older than the girls in the group. Women also discussed how they would like to have the opportunity to do some of the nonresearch related activities, such as making soap or playing tag with the girls. Women determined that the perspectives, experiences and priorities of girls were valuable and that the study design needed to be modified to ensure that everyone had the opportunity to participate fully throughout the entire evening. The study design was modified accordingly. All participants were involved in determining topics for discussion, activities that should be completed and areas in which they would like to see skill development opportunities. Girls also completed all the same activities as the adults, either independently or with the adult they came with. This allowed for rich results that provided a point for comparison between the perceptions of adults and girls. Women would ask girls to answer questions, guide discussions and complete activities first, and then would provide commentary on what the girls had shared.

\section{Increasing Opportunities for Self-Determination, Reflection and Knowledge Exchange}

Within this study, both women and girls often seemed to feel uncomfortable acting in decisionmaking capacities. While the research team anticipated a certain level of unease, and that the length of time to complete activities may differ based on individual participants needs and interests, for example children with shortened attention spans or adults with lower literacy levels, the extended time seemed to result from challenges in making decisions. Even the act of choosing a colour for a name tag during week one was challenging for some participants. As the weeks went on, everyone learned to freely praise one another, and to build upon their experiences in the study, such that the process of decisionmaking became less daunting for participants. The phrases 'I dunno' and 'no one asked me these things before' were replaced by overt decisions, such as 'let's eat now and do the game later'. Reassurance for decisions made was given and participants became more comfortable and confident with the process of public self-determination within the context of the workshop.

It was difficult for participants to actively participate in planning. Many adults and girls expressed that they had not had the opportunity to provide input into activities conducted within a formal setting before. Adults also asserted that beyond planning for major activities, such as career changes or the purchase and renovation of homes, they did not spend a lot of time thinking about the smaller choices in daily life. Women indicated that a primary reason for attending the workshop was the 
ability to learn what they can do to be happy, healthy and safe. Women in each group explained that they did not have confidence in their own capacity to make decisions that would lead to these results, or to teach their children the tools necessary to reach these ends.

Many of the activities conducted within the workshop emerged from expressed challenges or knowledge gaps identified by participants. Participants were aware that part of the researcher objectives were to learn about what their priorities and interests were, in addition both women and girls identified that they were participating because they wanted the workshop to be a space of engaged learning and relationship building between women and girls. The skill level within the groups varied extensively. Activities were designed with the intention of resonating with Indigenous knowledge and approaches to learning. These activities provided the opportunity to better assess what the barriers were that led to gaps in knowledge or practice, and to provide the opportunity for capacity building and growth.

\section{Medicine Wheel Game: Addressing Balance and Wellbeing}

The concerns that led to the development of this activity involved group consensus about a gap in knowledge following a session about self-care. Participants noted a lack of understanding about the difference between emotional and mental health. These are two distinct categories on the medicine wheel, according to one commonly used interpretation of the medicine wheel, and are important aspects of wellbeing. Many participants identified with the medicine wheel and saw it as a key cultural component to share among family members and communities to support and strengthen relationships.

To address this issue, a medicine wheel that could be tossed around the room was created. Participants stood in a circle, and when they caught the medicine wheel they provided an example of something they do for the quadrant they were holding. Examples pertained to emotional health, physical health, mental health, and spiritual health. Participants provided commentary on the issues raised. This was a good activity for participants to also begin conversations about items they found challenging to discuss, such as what they do for their emotional wellbeing.

Researcher: What do you do for your body?

Girl: I eat healthy stuff.

Researcher: What do you do for your spirit?

Woman: I take walks with my daughter.

Woman: To get your mind working? What do you do for your mind?

Girl: I dunno.

Woman: What do you do at school?

Girl: I draw. 


\section{Girl: For your emotion?}

Woman: For my emotions? I have a nice shower or a nice hot bath.

By using a medicine wheel, this activity provided a starting place for women and girls to discuss finding balance in their lives through a culturally relevant and often used image. While the image of the medicine wheel was drawn numerous times by participants, the multiple teachings associated with the medicine wheel was less familiar. Once participants began to name their experiences and perspectives, they were able to identify areas in their lives that they felt could be improved.

\section{Memory Game: Addressing Gaps in Knowledge about Basic Hygiene Supplies}

During a self-care night, participants made soap and painted their fingernails. Participants raised questions about the difference between liquid and bar soap. Initial questions were answered in the moment, but as people continued to talk, it was recognized that this was a larger gap within the knowledge base of multiple participants. Girls also discussed challenging risk-taking activities associated with the use of every-day objects, such as self-harm and substance abuse. Within the moment, no positive or negative response was provided, and participants were redirected to another activity. To try to address gaps in knowledge in a respectful way in the following week, participants, the lead researcher and the research assistant played a modified version of the memory game called 'Kim's Game'. This is a common game played by youth groups in Winnipeg. The majority of girls were familiar with this particular memory game. A number of household items commonly found in bathrooms were brought. These included, but were not limited to: hair ties, cotton balls, Q-tips, nail polish, hand soap, body wash, Band-Aids, feminine hygiene supplies and nail clippers. Participants had the opportunity to identify and ask questions about what the items were before the game began. Everyone sat in a circle around a selection of about twenty items. Within a typical 'Kim's Game', participants would look at the items and then close their eyes. All items would be covered, often with a sheet, and then participants were asked to list all they remember. The game was adjusted, and an item was removed by a girl while other participants closed their eyes. Participants had to identify the missing item. Discussion followed about the item, what it was used for and when it should or should not be used. The following excerpt discusses the uses for cotton swabs (referred to within this context by the brand-name Q-tip).

Researcher: What's missing?

An array of answers, then...

Girl: The Q-Tip.

Woman: Good job, kiddo.

Researcher: When do you use Q-Tips?

Girl: For ears.

Girl: If there's something in there ...[points to her ears].

Girl: Ear wax. 
Woman: After your shower.

Researcher: Is it good to use those in your ears?

Yes/No Collective response from women and girls.

Researcher: No, you're not supposed to. Why are you not supposed to use Q-Tips in your ears?

Woman: Cause it pushes it down.

Researcher: What can happen if you push the wax and stuff down further?

Girl: If you push it down too far it could actually rip your ear.

Woman: Eardrum.

Girl: You could get an earache.

Girl: I watched this YouTube video. You can actually put them in those clip bobby pins and then you can put them like little dots in your hair.

Girl: Eye shadow.

Girl: To put on lipstick.

Girl: Nail polish remover.

Researcher: Cleaning other stuff that's hard to get into right?

Woman: You can clean the keyboard.

Collective response from women and girls: Oh, ya!

Researcher: Can you reuse Q-Tips?

Collective response from women and girls: NOOO.

Researcher: Okay. I'll have to remember that.

Girl: You have to throw it out.

A researcher, acting as a workshop facilitator, would ask various questions about the items to encourage open discussion. Participants followed this lead and questioned the use of items. This activity provided the starting point for dialogue on a number of different issues such as access to feminine hygiene supplies, risk behaviours that girls may potentially engage in to be able to access female hygiene supplies which further led to a discussion about virginity, menstruation, and pregnancy. Participants discussed how they did not have all the items used in the game. Participants discussed why they might or might not use an item and what the barrier was. Barriers identified included cost, knowledge of what an item is, as well as relevance to daily lives. An important part in the decolonizing process is the ability to find ways to unpack tacit knowledge and experiences (Kovach, 2009). This exercise provided the opportunity to address gaps in knowledge that were potentially dangerous. It also provided the opportunity for self-determination and the sharing of knowledge.

\section{People like Me: Media Representations and Self-Determination}

The concern that led to the development of this activity was the lack of positive visual representation of Indigenous women in media, namely: if a girl does not see herself in the images in popular media, what standard of beauty is she expected to live up to? Participants did not find the 
existence of a standard of beauty problematic, but they were uncomfortable with the lack of diverse representations. Two weeks prior to the commencement of data collection, a First Nations woman from Alberta was crowned Mrs. Universe, with an active Indigenous rights platform ("Cree Woman from Alberta”, 2015). Many participants discussed this as a positive step for the recognition of Indigenous women as emerging leaders in re-defining beauty. Participants then discussed within this context how they were encouraging their daughters to begin to audition for acting and modeling jobs, but deconstructing this notion was initially beyond the scope of this research. This changed following concerns both adult and girls raised over the written statement by one of the 9 year olds: "I'm pretty, but I don't think I am".

A variety of magazines, including active living, fashion, nature, household and children's magazines, were collected. Girls and women cut out pictures of images they liked and images they did not like. Women talked about how being able to explain why you like or do not like an item is an important skill for girls to develop. The images people liked were glued to the outside of a blank journal to make a collage. The images people did not like were glued on a piece of paper that girls identified as something they did not want to keep in perpetuity, unlike their journals.

While cutting out pictures, participants discussed standards of beauty, Photoshop, and realistic expectations. The images that were included on the journal covers included some fashion accessories. Most of the items were food, animals, nature, and activities that could be done together. When girls discussed the images, they selected things they liked. The importance of imagination, pride and belief in themselves became evident.

Mila, girl: I could survive on a desert island. I have mad [amazing] skills.

Mila's mother: What skills?

Mila: I have the skill that if I get hungry I can wait a long time.

Mila's mother: That is a skill. What if you had your bow with you, what could you do with that?

Mila: I could shoot animals to eat. Like wild pigs.

Images on the negative poster included pictures of girls or women who did not look like they were being active, such as women draped over furniture or wearing very high heels. Other images included medications and other items that should not be marketed within magazines aimed at young adults or the general public.

We didn't like it because it's an advertisement for nail polish and I guess you don't need a top coat for it. The girl is topless with her hands in front of her chest and it says in big bold font 'go topless' we just don't think it's a good image for young girls. (Kandace, adult. Summarizing a group conversation). 
Girls wanted to discuss things they liked to do, and they wanted to talk about how their interests and expectations matched with popular discourse. The ability of women to reflect critically on the images presented within popular media, while thinking about the self-esteem of girls was salient for participants. Women reported that they had not thought about discussing these ideas with their daughters before. Girls talked about things they like to do, such as running, climbing, hunting and eating pancakes, verbalizing that they did not want to look like the women in the magazines who might not be able to be self-sufficient. This discussion led to the need for more realistic images of women and girls. Girls identified that being pretty means being able to look like you can do anything you want to do. Participants would like to see more Indigenous women and girls leading full, happy, successful lives in popular media imagery. At the end of the activity, women reflected on their observations, both of media and of their daughters' responses to images. One mother hoped her daughters would become models and be able to influence the depiction of Indigenous women through that method, whereas the other mothers would like their daughters to be able to critically examine the images they see and the feelings those images instill within them. Decorating the outside of a journal as a discussion point of what makes them happy, what they are good at, and what they are proud of set tone for the type of information that they reported writing in their journals. The mothers gave the journals to the girls, and the girls reported sharing the information that they wrote with their mothers, as there was a joint sense of ownership over the journal since the collage on the outside of the journal was created collectively by girls and their female familial caregivers.

\section{Limitations}

This project was conducted with women and girls age 8-12. All children lived with family members. While it is plausible that these approaches and findings could apply to girls of other age brackets, boys, and children who are not living within family contexts, more research would need to be conducted to verify these assumptions. Participants self-identified as First Nations and Metis living within an urban space on the Canadian prairies, as such generalizability of findings to rural and remote communities, the general population, other Indigenous groups, as well as other minority groups should be done with caution. Participants self-selected to participate in this study, demonstrating a desire to be involved in a project that focused on intergenerational experiences and health. As such, there may be a bias in terms of who agreed to partake in the study. The results did not appear to vary due to family size, age of caregiver, socioeconomic status, employment status or education level and all participants noted personal skill development and improved family relationships throughout their involvement in this study. 


\section{Discussion}

One of the greatest predictors of health and wellbeing is the ability to have both individual and collective self-determination (Aboriginal Children in Care Working Group, 2015; Reading \& Wien, 2009). The Canadian Constitution enshrines the right for women to have their voices heard and recognized. Although their cultural traditions are protected (Government of Canada, 1982), voices often remain silenced, as women, as Indigenous women, and as Indigenous peoples (Martin, 2012). It is only in the past fifty years that Indigenous women have started to see and document changes as they strive to reclaim legal autonomy within Canada (Dorion, 2003; Green, 2007; Welsh, 1991). Within this study, participants were encouraged to take ownership of the research space, to help shape the direction of the study and to determine what they needed in order to be satisfied with participation. Self-determination ultimately improves both mental and physical health, as people are able to make decisions that better reflect their needs (Canadian Reference Group World Health Organization Commission, 2006). Within this study, voicing decisions and making choices proved difficult for many of the participants. While it is impossible to empower someone, as empowerment must come from within, it is possible to provide skills, tools, and opportunities through which a person can voice his or her thoughts, experiences and engage in active decision making (Kirmayer et al., 2003; Rappaport, 1995; Williams \& Ferber, 2008). Participants discussed their concerns more readily as relationships formed both with the lead researcher, research assistant and one another.

The question of how to improve cultural continuity among families and communities proved to be an interesting point of discussion. Cultural continuity is recognized as a protective factor to ensure health and wellbeing (Chandler \& Dunlop, 2015; Chandler \& LaLonde, 2009) and was an issue that families wanted to discuss within the research setting. Historically children were raised within communities and would have a large support-network within their communities of adults they could turn to for assistance as they navigated their environments, both physical and relational (Carrière-Laboucane, 1997; de Finney, 2014; Henderson, Dinh, Morgan \& Lewis, 2015; National Collaborating Centre on Aboriginal Health, 2015, Rink, Ricker, FourStar \& Hallum-Montes, 2016; Welsh, 1991). By working together, participants and researchers were able to create a research environment where participants could, and would, provide advice to one another, answer questions and determine next steps. Children and adults were able to grow together and gain new skills, both tangible skills and knowledge as well as tacit skills learned from engagement with one another, such as different ways to engage in a positive way within family units. The more involvement female caregivers have with their daughters, the better girls are able to focus, and the lower the rates of aggression (Tramonte, Gauthier \& Willms, 2013). Girls will mirror what they see (Benn, 2013). As the weeks passed, participants became more vocal about what their interests were. They began to openly identify challenges they were experiencing, such as limitations with health messaging and with public advertisements, especially those that encouraged the objectification of female bodies rather than encouraging skill building and self-esteem among young women. Unpacking the barriers to knowledge uptake, such as a lack of representative images found 
within public communication materials was an aspect participants indicated was key for them to gain new information and share knowledge both within and outside the research workshop environment pertaining to self-determination and decision-making practices.

\section{Conclusion}

Involving participants in an ongoing decision-making process whereby their priorities and goals are the focus of research is a crucial step to understanding the health and wellness interests of Indigenous communities. Their involvement is also essential to understanding needs and to continue to work together towards addressing participant visions for what research within intergenerational spaces can, and should be. Within this study, girls and women took a lead role in identifying the contexts that were important in addressing and prioritizing the content for weekly activities. Initially, this proved challenging for many participants. Creating a research space where people were encouraged to voice their opinions was essential (Cooper \& Driedger, 2019). This space provided a venue for shared learning. It also provided opportunities to address challenges individuals identified within their lives, for growth in confidence and self-determination, and pride in community.

\section{References}

Aboriginal Children in Care Working Group. (2015). Aboriginal children in care: Report to Canada's Premiers. Ottawa, ON. Retrieved from http://canadaspremiers.ca/phocadownload/publications/aboriginal_children in care repo rt july2015.pdf.

Adelson, N. (2009). Toward a recuperation of souls and bodies: Community healing and the complex interplay of faith and history. In L. J. Kirmayer \& G. Guthrie Valaskakis (Eds.), Healing Traditions: The mental health of Aboriginal peoples in Canada (pp. 272-314). Vancouver, BC: UBC Press. ISBN: 978-0774815246

Cooper, E.J., \& Driedger, S.M. (2019). "If You Fall Down, You Get Back Up”: Creating a Space for Testimony and Witnessing by Urban Indigenous Women and Girls. The International Indigenous Policy Journal, 10(1). doi: 10.18584/iipj.2019.10.1.1

Blumenthal, D. S. (2011). Is community-based participatory research possible? American Journal of Preventative Medicine, 40, 386-389. doi:10.1016/j.amepre.2010.11.011

Braun, V., \& Clarke, V. (2006). Using thematic analysis in psychology. Qualitative Research in Psychology, 3, 77-101. doi:10.1191/1478088706qp063oa

Carrière-Laboucane, J. (1997). Kinship care: A community alternative to foster care. Native Social Work Journal, 1(1), 43-53.

Canadian Reference Group World Health Organization Commission. (2006). Aboriginal Dialogue: Canadian reference group World Health Organization commission- Social 
determinants of health. Surrey, BC. Retrieved from:

http://www.unbc.ca/assets/nccah/english/papers/aboriginal_dialogue proceedings_exe c_summary.pdf

Chambers, R. (2002). Participatory workshops: A sorcebook of 21 sets of ideas and activities. London: Earthscan. ISBN: 978-1853838620

Cree woman from Alberta crowned Mrs. Universe 2015. (2015, August 30). Globe and Mail. Retrieved from https://beta.theglobeandmail.com/news/world/cree-woman-from-albertacrowned-mrs-universe-2015/article26159935/?ref=http://www.theglobeandmail.com\&.

de Finney, S. (2014). Under the shadow of empire: Indigenous girls' presencing as decolonizing force. Girlhood Studies, 7(1), 8-26. doi:10.3167/ghs.2014.070103

Duran, E., Duran, B., Yellow Horse Brave Heart, M., \& Yellow Horse-Davis, S. (1998). Healing the American Indian soul wound: International handbook of multigenerational legacies of

trauma, 341-354. doi: https://doi.org/10.1007/978-1-4757-5567-1_22

Episkenew, J.-A. (2009). Taking back our spirits: Indigenous literature, public policy and healing. Winnipeg, Manitoba: University of Manitoba Press. ISBN: 9780887557101

Funston, L. (2013). Aboriginal and Torres Strait Islander worldviews and cultural safety transforming sexual assault service provision for children and young people. International Journal of Environmental Research and Public Health, 10, 3818-3833. doi:10.3390/ijerph10093818.

Government of Canada. (1982). The Constitution Acts, 1867 to 1982. Ottawa: Queen's Printer Retrieved from http://laws-lois.justice.gc.ca/PDF/CONST_E.pdf.

Guest, G., MacQueen, K. M., \& Namey, E. E. (2012). Applied thematic analysis. Thousand Oaks, CA: Sage Publications Inc. ISBN: 9781412971676

Green, J. (2007). Taking account of Aboriginal feminism. In J. Green (Ed.), Making space for Indigenous feminism (pp. 20-32). Winnipeg, MB: Fernwood Publishing. ISBN: 9781552662205.

Hankivsky, O., Grace, D., Hunting, G., Giesbrecht, M., Fridkin, A., Rudrum, S., . . Clark, N. (2014). An intersectionality-based policy analysis framework: Critical reflections on a methodology for advancing equity. International Journal for Equity in Health, 13(119). doi: https://doi.org/10.1186/s12939-014-0119- x

Henderson, T.L., Dinh, M., Morgan, K., Lewis, J. (2015). Alaska Native grandparents rearing grandchildren. Journal of Family Issues, 38(4), 547-572. doi:

https://doi.org/10.1177/0192513X15597292

Kirmayer, L. J., Simpson, C., \& Cargo, M. (2003). Healing traditions: Culture, community and mental health promotion with Canadian Aboriginal peoples. Australasian Psychiatry, 11, S15-S23. doi:10.1046/j.1038-5282.2003.02010.x

Kovach, M. (2009). Indigenous methodologies: Characteristics, conversations and contexts. Toronto, ON: University of Toronto Press. ISBN: 9781442640429

Linklater, R. (2014). Decolonizing trauma work: Indigenous stories and strategies. Winnipeg, 
MB: Fernwood Publishing. ISBN: 9781552666586

Martin, D. (2012). Two-eyed seeing: A framework for understanding Indigenous and nonIndigenous approaches to Indigenous health research. Canadian Journal of Nursing Research, 44(2), 20-42.

Minkler, M. (2005). Community-based research partnerships: challenges and opportunities. Journal of Urban Health, 82(2 Supplement), ii3-ii12. doi: [10.1093/jurban/jti034]

National Collaborating Centre for Aboriginal Health. (2015). Family is the focus: Proceedings summary. Prince George, BC: National Collaborating Centre for Aboriginal Health.

Prussing, E. (2014). Historical trauma: Politics of a conceptual framework. Transcultural Psychiatry, 51(3), 436-458. doi: http://dx.doi.org/10.1177/1363461514531316

Rappaport, J. (1995). Empowerment meets narrative: Listening to stories and creating settings. American Journal of Community Psychology, 23(5), 795-807. doi:10.1007/BF02506992

Reading, C. L., \& Wien, F. (2009). Health inequalities and social determinants of Aboriginal peoples' health. Prince George, BC Canada.

Rink, E., Ricker, A., FourStar, K., Hallum-Montes, R. (2016). "A balance that we walk" Characteristics, attributes, and behaviours that promote healthy American Indian heterosexual couple relationships. Journal of Family Issues, 39(3), P. 817-840 doi: $10.1177 / 0192513 X 16680091$

Rothe, J. P., Ozegovic, D., \& Carroll, L. J. (2009). Innovation in qualitative interviews: "Sharing circles" in a First Nations community. Injury Prevention, 15(5), 334-340. doi: 10.1136/ip.2008.021261

Schwan, K. J., \& Lightman, E. (2015). Fostering resistance, cultivating decolonization: The intersection of Canadian colonial history and contemporary arts programming with Inuit youth. Cultural Studies Critical Methodologies, 15, 15-29. doi:10.1177/1532708613509373

Strong-Boag, V. (2011). Fostering nation? Canada confronts its history of childhood disadvantage. Waterloo, ON: Wilfrid Laurier University Press. ISBN: 9781554582549

Tasker, J.P. (2017). Ottawa announces \$800M settlement with Indigenous survivors of Sixties Scoop. CBC News. Retrieved from: http://www.cbc.ca/news/politics/ottawa-settle-60sscoop-survivors-1.4342462

Tramonte, L., Gauthier, A., Willms, J.D. (2013). Engagement and Guidance: The effects of maternal patenting practices on children's development. Journal of Family Issues. 36(3), 396-420. doi: https://doi.org/10.1177/0192513X13489959

Truth and Reconciliation Commission of Canada. (2015). Honouring the truth, reconciling for the future: Summary of the final report of the Truth and Reconciliation Commission of Canada. Retrieved from Ottawa, Ontario:

http://www.trc.ca/websites/trcinstitution/File/2015/Findings/Exec Summary 2015053 1_web_o.pdf

Tuhiwai-Smith, L. (2006). Decolonizing methodologies: Research and Indigenous peoples. New York, NY: Zed Books. ISBN: 9781856496230 
Walker, M., Fredericks, B., Mills, K., \& Anderson, D. (2014). "Yarning" as a method for community-based health research with Indigenous women: The Indigenous women's wellness research program. Health Care for Women International, 35(10), 37-41. doi:10.1080/07399332.2013.815754

Wang, C., \& Burris, M. A. (1997). Photovoice: Concept, methodology, and use for participatory needs assessment. Health Education and Behavior, 24(3), 369-387. doi: $10.1177 / 109019819702400309$

Welsh, C. (1991). Voices of the grandmothers: Reclaiming a Métis heritage. Canadian Literature, 131, 15-24.

Williams, R. L., \& Ferber, A. L. (2008). Facilitating Smart-Girl: Feminist pedagogy in service learning in action. Feminist Teacher: A Journal of the Practices, Theories, and Scholarship of Feminist Teaching, 19(2), 47-67. doi:10.1353/ftr.0.0027

Yellow Horse Brave Heart, M. (2003). The historical trauma response among Natives and its relationship with substance abuse: A Lakota illustration. Journal of Psychoactive Drugs, 35(1), 7-13. doi:10.1080/02791072.2003.10399988 


\section{Appendix 1.}

Nutrition Night Session Guide.

\begin{tabular}{|c|c|c|c|}
\hline $\begin{array}{l}\text { Length of } \\
\text { activity } \\
\text { (minutes) }\end{array}$ & Activity & Data Collected & $\begin{array}{l}\text { Skill Building } \\
\text { Opportunity }\end{array}$ \\
\hline $\begin{array}{l}\text { Before the } \\
\text { start and the } \\
\text { first } 10 \\
\text { minutes }\end{array}$ & $\begin{array}{l}\text { Children prepared "apple smiles" for } \\
\text { desert while participants arrived. } \\
\text { This involved cutting up an apple, and } \\
\text { placing peanut butter and mini } \\
\text { marshmallows between two apple slices to } \\
\text { create a "smile" }\end{array}$ & $\begin{array}{l}\text { Photographs } \\
\text { Capacity building }\end{array}$ & Cooking skills \\
\hline 5 & $\begin{array}{l}\text { Discussion about how we might describe } \\
\text { food }\end{array}$ & $\begin{array}{l}\text { Discussion about } \\
\text { food qualities }\end{array}$ & \\
\hline 10 & $\begin{array}{l}\text { Matching game- a picture was taped to } \\
\text { each person's back. } \\
\text { They had to figure out the object taped to } \\
\text { their backs by asking questions. Once } \\
\text { participants knew who they were they } \\
\text { would find their commonly matched pair. } \\
\text { Food pairs included milk and cereal, } \\
\text { veggies and dip and soup and crackers }\end{array}$ & None & $\begin{array}{l}\text { Relationship building } \\
\text { Communication skills }\end{array}$ \\
\hline 20 & $\begin{array}{l}\text { Participants helped prepare food } \\
\text {-Women wanted to learn how to de-bone } \\
\text { chicken, so this skill was covered. } \\
\text {-Girls prepared a salad } \\
\text {-Participants learned/reviewed how to } \\
\text { make stock out of the leftover "garbage" } \\
\text { (chicken bones, skin, vegetable peels etc.) }\end{array}$ & $\begin{array}{l}\text { Field/observation } \\
\text { notes }\end{array}$ & Cooking skills \\
\hline 20 & $\begin{array}{l}\text { Astronaut Activity- participants learned } \\
\text { about how food is planned and prepared } \\
\text { for astronauts traveling to space. } \\
\text { Families were asked to plan two days } \\
\text { worth of meals if they were going to go to } \\
\text { space. Flyers from local grocery stores } \\
\text { were provided. Participants cut out } \\
\text { pictures, drew pictures and wrote down } \\
\text { words to plan meals for their space } \\
\text { adventure. }\end{array}$ & $\begin{array}{l}\text { Meal plans were } \\
\text { photographed to } \\
\text { be reviewed for } \\
\text { food choices }\end{array}$ & $\begin{array}{l}\text { Meal planning, using } \\
\text { coupons to budget. }\end{array}$ \\
\hline 40 & $\begin{array}{l}\text { Dinner: teriyaki chicken, rice, salad and } \\
\text { "apple smiles" }\end{array}$ & None & \\
\hline
\end{tabular}




\begin{tabular}{|c|c|c|c|}
\hline 15 & $\begin{array}{l}\text { Tooth Brushing Game: each family was } \\
\text { given a package of cookies. Participants } \\
\text { ate as many cookies as they could in } 30 \\
\text { seconds. Note: as this activity was after } \\
\text { dinner, most ate between 1-3 cookies. } \\
\text { Videos were taken of girls (and some } \\
\text { adults) showing off their "disgusting } \\
\text { mouth" filled with cookie crumbs. } \\
\text { Participants were given tooth brushes and } \\
\text { toothpaste and given } 2 \text { minutes to brush } \\
\text { their teeth. } \\
\text { "After" videos were taken. Participants } \\
\text { examined each other's teeth to see how } \\
\text { good a job they did and then discussed } \\
\text { knowledge about oral hygiene. } \\
\text { Every participant was a "winner" and got } \\
\text { an oral hygiene related prize such as a } \\
\text { toothbrush holder or dental floss. }\end{array}$ & $\begin{array}{l}\text { Video of mouths } \\
\text { assess brushing } \\
\text { knowledge. } \\
\text { Video recording } \\
\text { of discussion. } \\
\text { Field/observation } \\
\text { notes }\end{array}$ & $\begin{array}{l}\text { Women were surprised } \\
\text { at the lack of proper } \\
\text { teeth brushing for their } \\
\text { daughters. Participants } \\
\text { were surprised to learn } \\
\text { about oral hygiene } \\
\text { practices. } \\
\text { Participants were happy } \\
\text { to get new } \\
\text { toothbrushes. }\end{array}$ \\
\hline 10 & $\begin{array}{l}\text { Examining Eggs. Hard boiled eggs had } \\
\text { been placed in containers containing either } \\
\text { milk, juice, water, coffee, or cola earlier in } \\
\text { the day. } \\
\text { The eggs were removed one by one and } \\
\text { participants discussed their observations. } \\
\text { A discussion about how eggs are similar to } \\
\text { the enamel on teeth and the importance of } \\
\text { brushing teeth daily finished the activity. }\end{array}$ & $\begin{array}{l}\text { Video discussion } \\
\text { recorded } \\
\text { Field/observation } \\
\text { notes }\end{array}$ & $\begin{array}{l}\text { Tangible discussion } \\
\text { about the importance of } \\
\text { brushing teeth } \\
\text { In future weeks, milk } \\
\text { and water consumption } \\
\text { increased and juice } \\
\text { decreased. Adults } \\
\text { discussed how girls } \\
\text { were drinking more } \\
\text { milk and water and less } \\
\text { pop and juice at home. } \\
\text { This change spanned } \\
\text { the duration of the } \\
\text { workshop. It is } \\
\text { unknown if it continued } \\
\text { after. }\end{array}$ \\
\hline 5 & $\begin{array}{l}\text { Closing and overview of the following } \\
\text { week }\end{array}$ & Field notes & $\begin{array}{l}\text { Ability to determine } \\
\text { specific requests for the } \\
\text { following session and } \\
\text { evaluate the current } \\
\text { week. }\end{array}$ \\
\hline
\end{tabular}

